\section{2-Heptanone in the Mandibular Gland Secretion of the Honey-bee}

WORKer honey-bons produce alarm pheromones in their sting apparatus and in thoir mandibular glands'. One of the components of the sting pheromono ${ }^{2}$ has boon identified a.s isoamyl acotate which roleasos strong alarm behaviour in boos. When filtor paper treated with isoamyl acetato is placed at the hive entrance the beos nearby become alerted and greatly agitated. They assume a characteristic aggressive posture and run jerkily in circles or short zigzags preferentially toward the papor. The same behaviour can be observed when mandibular glands or crushed heads of worker bees aro presented at the hive ontrance.

The secretion contained in the mandibular gland roservoir has a strong smoll which, according to $\mathrm{Forol}^{3}$, is quite similar to that of the secretion of tho anal glands of certain ants (for example, Tapinoma erraticum, Latr.).

We have identified an alarm substance from the mandibular glands of the honey-bee as 2-heptanone.

Hoads of bees were collected and held at dry-ice tomperature until used. Pentane or petroloum ether $(0.5 \mathrm{ml}$.) was added to 10 heads which wore then crushed with a flat-ended spatula and mixod thoroughly with the solvent. After centrifuging, the supernatant liquid was drawn off and a 5 - $\mu$ l. aliquot was injoctod into a MicroTek $G C 2500 R$ gas chromatograph equipped with a hydrogen flame ionization detector. In the lower molecular sizo range a single prominent peak was prosont. A typical kotonic odour was readily dotoctable at the instrument outlet whon this componont emerged. The retention times on three difforont columns aro compared in Table 1 with those for an authentic sample of 2-hoptanono (purchased from Eastman Organic Chemicals, Rochester 3, Now York).

Table 1. Gas Cmromatography of Bef-mfan Extrauts $a T 70^{\circ} \mathrm{C}$

\begin{tabular}{|c|c|c|c|c|c|}
\hline \multirow[b]{2}{*}{ Column } & \multirow[b]{2}{*}{$\begin{array}{c}\text { Column } \\
\text { Bength } \\
\text { (ft.) }\end{array}$} & \multicolumn{4}{|c|}{ Retention times $(\min )$} \\
\hline & & $\begin{array}{l}\text { Thee head } \\
\text { com- } \\
\text { ponent }\end{array}$ & $\begin{array}{l}\text { 2-Hop- } \\
\text { tanone }\end{array}$ & $\begin{array}{l}\text { Reduced } \\
\text { bee head } \\
\text { component }\end{array}$ & $\begin{array}{c}\text { 2-Hep- } \\
\text { tanol }\end{array}$ \\
\hline $\begin{array}{l}L^{\prime} \\
M 20^{\prime}\end{array}$ & $\begin{array}{l}6 \cdot 5 \\
8 \\
4 \cdot 5\end{array}$ & $\begin{array}{l}6 \cdot 25 \\
7 \cdot 25 \\
2 \cdot 50\end{array}$ & $\begin{array}{l}6 \cdot 25 \\
7.2 \\
2 \cdot 50\end{array}$ & $\begin{array}{c}7 \cdot 78 \\
17 \cdot 4 \\
3 \cdot 9\end{array}$ & $\begin{array}{c}7 \cdot 72 \\
17 \cdot 1 \\
3 \cdot 8\end{array}$ \\
\hline
\end{tabular}

Column support: 'Anakrom $A R S^{\prime}$ 150/160 mesh. Carricr gas: nitrogen, $70 \mathrm{ml} . / \mathrm{min}$.

$\Lambda$ portion of the beo-head extract was treated in ether with sodium borohydride. The resulting alcohol was also subjectod to gas chromatography and the retention times (Table 1) are compared with a samplo of 2-heptanol.

From an extract of 200 hoads of forage bees a fraction was separated by gas chromatography and collected ${ }^{4}$ for analysis by infra-red spectrometry. The spectrum of the isolatod component was identical to that of authontio 2-heptanone. A 2,4-dinitrophenylhydrazono dorivative was prepared, but insufficient material was obtuined for a dotermination of the molting point. Howover, thin layor chromatography of the derivative on a "Kieselgel $G^{2}$ plate (chloroform developod) showed the same $R_{F}$ as a samplo of the 2,4-dinitrophenylhydrazono of 2-hoptanono.

In order to show that 2-heptanono did originate in the mandibular glands, the glands were excised from the hoads of five bees and were analysod aftor oxtraction with $0.1 \mathrm{ml}$. potroleum ethor. Tho yiold was $8.6 \mu \mathrm{g}$ of 2-heptinone per bees. This represents about 40 por cent of the amount rocovered from the crushed heads of foraging boos, which is in the rango of $15-23 \mu \mathrm{g}$ por boo. Tho difforence is probably due to loss during dissoction. Hoptanone was not recovered from boos which had not yet flown, nor from tho hoads of oither young or old quoons, nor from the hoads of drones.

Hexane extracts of heads of foraging boos and a solution of authentic 2-heptanone in parnffin oil were tested for their effoct on honey-boes. The substances wero applicd to small corks whieh woro sot one at a time on the alighting board diroctly in front of the entranco to the hive. Guard bees became alerted and agitated. These bees came forth from the hive and attackod the cork and removed it from the hivo ontrance. Control corks with paraffin oil alone did not elicit any of these roactions.

'This is the first reportod occurrence of a heptanono in boes. However, in the dolichodorino ant, Iridomyrmex pruinosus, Roger, 2-heptanono has been identified as a constituent of its alarm substances ${ }^{8}$.

Analytical Chemistry Research Sorvico,

$$
\text { D. A. Shearer }
$$

Entomology Research Institute,

Canada Department of Agriculture,

$$
\text { Ottawa. }
$$

1 Maschwitz, U., Z. vergl. Physiol., 47, 596 (1964).

8 Boch, R. Shearer, D. A., and Stone, B. C., Nature, 195, 1018 (1962).

s Forel, A., The Senses of Insects (Methuen, London, 1908).

- Shearer, D. A., Stone, B. C., and McGugan, W. A., The Analyst, 88, 147 (1063).

$\checkmark$ Blum, M. S., Warter, S. L., Monroc, R. S., and Chidester, J. C., J. Insect Physiol., 9, 881 (1903).

\section{MICROBIOLOGY}

\section{Nucleotide Composition of Soluble Ribonucleic Acid of Streptomyces fradiae}

THE nucleotide composition of bacterial DNA vitrios widely from specios to spocies and the $G+C$ moles per cent particularly range from 30 to 70 . Instead, the $G+C$ moles per cent of $s \mathrm{RNA}$ seem to romain at about $60-62$ per cent in almost all species examined. A few results were availablo for species with high $G+C$ DNA content; thus, in order to explore this rango in other bacterial species, we have examined tho nucleotide composition of tho $s$ RNA of Streptomyces fradiue PSA 156 (DNA $G+C$ content of this strain is 72.4 from buoyant density and 78.5 from tomperature of denaturation midpoint determination $)^{1}$.

The cells were grown at $30^{\circ}$ while shaking in a medium containing 0.5 per cent 'Bactopeptone', 0.3 per cent yoast extract, $0 \cdot 2$ por cont boef extract, $0 \cdot 1$ per cent casaminoacids and $0 \cdot 1$ per cent glucose. After sovornl hours, the cells were collected and washed in $0.01 \mathrm{M}$ tris buffer $(p \mathrm{H}$ $7 \cdot 3$ ) containing 0.01 magnesium acetate.

$s$ RNA was prepared according to the mothod of Tis. sières ${ }^{2}$ from the bactorial extract from which the ribosomal fraction had been carefully removed (180 min at $105,000 \mathrm{~g})$. Ultracentrifugal aralyses showod that the sedimentation coefficient of purified $s$ RNA was $4 S$.

Spectrophotometrical analyses revoaled tho characteristic absorption spectrum of RNA.

sRNA was precipitated by cold $0.5 \mathrm{M}$ PCA, subjocted to $0.3 \mathrm{M} \mathrm{KOH}$ hydrolysis for $18 \mathrm{~h}$ at $37^{\circ} \mathrm{C}$, then adjusted to $p \mathrm{H} \mathrm{I}$ and $p \mathrm{H} 3.5$ with cold $\mathrm{PCA}^{3}$. The nucleotides wore frnctionatod by paper electrophoresis in ammonium formato buffor $p \mathrm{H} 3.5$ at $1,000 \mathrm{~V}, 4 \mathrm{~m} . \mathrm{amp}$, for $5 \mathrm{~h} 30$ $\min ^{4}$. On the electrophoresis papor the spots were clear and separatod. The guanilic acid spot extended dividing two components, both of which showed tho samo characteristic absorption spectrum of guanilic acid. Following tho method of Davidson and Smellie, we retained theso two components isomeric guanilic acids and proporly guanilic $2^{\prime}$ and $3^{\prime}$ phosphate. In tho result the value of guanilic acid comprisod both isomeric compounds.

The separated bands wero oluted in $p \mathrm{H} 21 \mathrm{~N}$ formic acid and ultra-violot absorbancy of the eluate was detormined.

The results were expressed as molos of each component, por cent moles of all nucleotides.

The analysos of nucleotide composition showed: adenylic acid, 19.5 per cent; cytydilic weid, 26.8 por cent; guanilic acid, 35.2 per cont; and uridylic acid, 18.5 per cent.

The standard deviation for the mean values of cach componont was in the rance of $1 \cdot 2-2 \cdot 5$ per cent. 